\title{
Sebaran Infeksi Ektoparasit pada Ikan Mas di Jaring Apung Jatiluhur, Cirata, Saguling, Jatigede, Darma, Provinsi Jawa Barat
}

\author{
[The Distribution of Ectoparasites Infection in Carp Fish in Floating Net located \\ in Jatiluhur, Cirata, Saguling, Jatigede, and Darma, West Java province]
}

\author{
Yuke Eliyani \\ Jurusan Penyuluhan Perikanan - Sekolah Tinggi Perikanan \\ Jalan Cikaret Nomor 2 Kota Bogor 16001, Jawa Barat
}

Diterima: 20 Februari 2018; Disetujui: 31 Maret 2018

\begin{abstract}
Abstrak
Penelitian ini bertujuan untuk mengidentifikasi serangan infeksi ektoparasit pada ikan mas (Cyprinus carpio) yang dipelihara di jaring apung Jatiluhur, Cirata, Saguling, Jatigede serta Darma Provinsi Jawa Barat, pada bulan Agustus 2017. Identifikasi dan analisa ektoparasit dilaksanakan di Laboratorium Kesehatan Ikan, Departemen Akuakultur, Institut Pertanian Bogor. Hasil identifikasi menunjukkan terdapat 10 jenis ektoparasit yang ditemukan, yaitu Trichodina sp., Ichthyophthirius multifilis, Epistylis sp., Vorticella sp., Argulus sp., Gyrodactylus sp., Dactylogyrus sp., Cichlidogyrus sp., Diplozoon sp., Heterobothrium sp. Dari 19 ektoparasit ini, terdapat 4 jenis ektoparasit yang ditemukan di semua lokasi penelitian yaitu: Trichodina sp., Diplozoon sp., Dactylogyrus sp., Cichlidogyrus sp; dengan kisaran nilai prevalensi (\%) $10-100$; nilai intensitas sebesar $1-225,2$; dan rentang nilai dominansi \% sebesar 0,05-93,39.
\end{abstract}

Kata kunci: Cyprinus carpio; dominansi; ektoparasit; intensitas; prevalensi

\begin{abstract}
This study aims to identify ectoparasite infection in carp fish (Cyprinus carpio) which is cultivated in folating nets located in Jatiluhur, Cirata, Saguling, Jatigede, and Darma West Java Province, in August 2017. Ectoparasites Identification and analysis was conducted at The Fish Health Laboratory, Department of Aquaculture, Bogor Agricultural University. Identification result showed that there were 10 types of ectoparasites found, that are Trichodina sp., Ichthyophthirius multifilis, Epistylis sp., Vorticella sp., Argulus sp., Gyrodactylus sp., Dactylogyrus sp., Cichlidogyrus sp., Diplozoon sp., and Heterobothrium sp. Among 19 ectoparasites mentioned, these 4 types were found in all study locations, which were Trichodina sp., Diplozoon sp., Dactylogyrus sp., and Cichlidogyrussp; the range of prevalence value (\%) was 10-100; intensity value was 1 - 225.2; and the range of dominance value (\%) was $0.05-93.39$.
\end{abstract}

Keywords: Cyprinus carpio; ectoparasites; dominance; intensity; prevalence

Penulis korespondensi

Yuke Eliyani | yukeeliyani@yahoo.co.id 


\section{PENDAHULUAN}

Waduk Jatiluhur, Cirata, Saguling Jatigede serta Darma merupakan lima waduk di Provinsi Jawa Barat yang salah satu pemanfaatannya adalah untuk pemeliharaan ikan di Jaring apung. Jumlah maksimum KJA di perairan Waduk Jatiluhur telah ditetapkan oleh Perum Jasa Tirta (PJT) II Jatiluhur sebanyak 4.000 petak, namun saat ini telah mencapai sekitar 21.000 sampai dengan 26.717 petak, sehingga air waduk tersebut telah terjadi eutrofikasi yang mengganggu peruntukan air lain-nya (Harsono 2016). Kegiatan budidaya ikan dengan menggunakan Keramba Ja-ring Apung (KJA) menyebabkan sema-kin tingginya kandungan bahan organik di Waduk Cirata. Menurut Irianto et al. (2012) dalam Novia (2016), keberadaan KJA menyebabkan meningkatnya beban limbah organik ke dalam waduk sebanyak $145.334 .000 \mathrm{~kg}$ per-tahun. Disamping itu, adanya beban polutan organik yang berasal dari dalam maupun luar waduk dapat mempengaruhi kualitas air di waduk.Kondisi waduk Saguling dan Jatigede juga sudah mengalami peningkatan kandungan bahan organik seiring dengan lamanya waktu pemeliharaan ikan di KJA.

Waduk Darma merupakan bendungan yang terletak di Desa Darma, Kecamatan Darma, Kabupaten Kuningan, Jawa Barat. Menurut data teknis dari
Kementerian Pekerjaan Umum, Ditjen SDA, pada Balai Besar Wilayah Sungai (BBWS) Cimanuk-Cisanggarung mengungkapkan bahwa luas daerah layanan Waduk Darma berdasarkan data tahun 2006/2007 meliputi Kabupaten Kuningan seluas $6.400 \mathrm{Ha}$ dan Kabupaten Cirebon 13.284 seluas Ha. Selain itu, air Waduk Darma juga digunakan untuk air baku PDAM Kuningan, Keramba Jaring Apung (KJA), dan pemanfaatan objek wisata (Hermawaty 2015).

Pengembangan budidaya perikanan, diantaranya KJA memerlukan input produki yang tinggi terutama pasokan pakan yang meningkat sejalan dengaan lamanya waktu pemeliharaan ikan. Kondisi ini akan diperparah dengan adanya masukan sisa metabolisme ikan ke dalam waduk. Tingginya sisa pakan dan metabolisme di badan air akan meningkatkan kandungan bahan organik, yang disisi lain merupaan salah satu faktor pencetus adanya serangan penyakit (Gonzalez et al. 2016). Salah satu jenis penyakit ikan adalah penyakit yang diakibatkan oleh infeksi parasit baik endo parasit maupun ektoparasit (Hashimoto et al. 2016).

Infeksi ekto parasit dapat menjadi salah satu faktor predisposisi bagi infeksi organisme patogen yang lebih berbahaya, yaitu berupa kerusakan organ luar, pertumbuhan yang lambat, 
penurunan nilai jual, dan peningkatan sensitivitas terhadap stressor (Handayani et al. 2004 dalam Marlan \& Sri 2014, Rolin et al. 2016, Skov et al. 2014). Penelitian ini bertujuan untuk mengidentifikasi sebaran serangan infeksi ektoparasit pada ikan mas (Cyprinus carpio) yang dipelihara di KJA Jatiluhur, Cirata, Saguling, Jati Gede serta Darma, pada bulan Agustus 2017.

\section{BAHAN DAN METODE}

Penelitian ini dilaksanakan pada bulan Agustus tahun 2017 di jaring apung Maleber (Waduk Cirata), jaring apung Cilalawi dan Pagadungan (Waduk Ir. H. Djuanda) di Jatiluhur, Waduk Darma di Kuningan, Waduk Saguling di Kabupaten Bandung, serta Waduk Jatigede di Kabupaten Sumedang Provinsi Jawa Barat. Pemeriksaan ektoparasit dilaksanakan di Laboratorium Kesehatan Ikan, Departemen Akuakultur, Institut Pertanian Bogor. Analisa sam-pel kualitas air dilaksanakan untuk Waduk Cirata, Saguling, Jatigede dan Darma dilakukan secara in situ, se-dangkan di Waduk Ir. H. Djuanda Jatiluhur dilaksanakan di Balai Pene-litian Pemulihan \& Konservasi Sumber Daya Ikan Purwakarta, Jawa Barat.

Populasi penelitian ini adalah ikan hasil tangkapan pada titik tertentu di setiap waduk yang menjadi lokasi penelitian. Jumlah total sampel ikan yang diperiksa sebanyak 15 ekor untuk setiap waduk. Rancangan penelitian ini merupakan penelitian eksplorasi dengan metode survei. Survei lapangan di lakukan langsung di lima Waduk lokasi penelitian. Pengamatan langsung kondisi ikan sampel serta adanya gejala ikan sakit dan ikan yang mati sebagai data pendukung. Pengambilan sampel ikan dilakukan bersamaan dengan pengambilan sampel air untuk kualitas air.

Peralatan yang digunakan dalam penelitian ini adalah object glass, cover glass, alat bedah/dissecting kit (gunting, pisau bedah, pinset ujung runcing, scalpel), pipet tetes, ember, nampan plastik, termometer, penggaris, alat tulis, kamera, mikroskop binokuler. Sedangkan bahan penelitian adalah: Ikan sampel, akuades, alkohol $70 \%$, test kit (DO, $\mathrm{NH}_{3}$, $\mathrm{pH}$,), oksigen murni dalam tabung, plastik packing, karet gelang, kertas label. Pengambilan sampel dilakukan satu kali pada bulan Agustus 2017. Sampel diambil langsung dari li-ma waduk lokasi penelitian, dan dimasukkan ke dalam kantong plastik yang telah diberi air dan oksigen dengan jumlah sampel sebanyak 15 ekor untuk setiap waduk; kemudian di bawa ke Laboratorium Kesehatan Ikan, Departemen Akuakultur, Institut Pertanian Bogor untuk pemeriksaan ektoparasit. Ikan yang digunakan dalam penelitian ini adalah ikan mas yang dipelihara di jaring 
apung pada waktu tertentu. Pengambilan data pendukung penelitian pada tahap ini antara lain kualitas air yaitu suhu air waduk, $\mathrm{pH}$, Oksigen terlarut, dan Amonia.

Pelaksanaan penelitian diawali dengan pengambilan lendir, insang serta siripdengan cara mengerok bagian kulit ikan, sisik, kepala sampai ekor menggunakan scalpel hingga mendapatkan lendir (cairan mucus). Kemudian lendir dengan buku identifikasi parasit menurut Kabata (1985). Data iden-tifikasi ektoparasit menurut serta dihi-tung jumlah ektoparasit yang terdapat pada ikan konsumsi. Adapun rumus yang digunakan untuk menganalisis tingkat serangan ektoparasit yaitu menggunakan perhitungan intensitas parasit menurut Prevalence of infection \%, (Malhotra et al. 1981) dalam Hamzah et al. (2017), sebagai berikut:

$$
\begin{gathered}
\text { Prevalensi }=\frac{\text { jumlah ikan sampel yang terserang }}{\text { jumlah ikan sampel yang diperiksa }} \times 100 \% \\
\text { Intensitas }=\frac{\text { jumlah ektoparasit } \mathrm{A} \text { yang menginfeksi }}{\text { jumlah ikan sampel yang terserang ektoparasit } \mathrm{A}} \times 100 \% \\
\text { Dominansi }=\frac{\text { jumlah satu ektoparasit yang menginfeksi ikan sampel }}{\text { jumlah total ektoparasit yang menginfeksi ikan sampel }} \times 100 \%
\end{gathered}
$$

diletakkan diatas object glass ditetesi akuades, ditutup dengan cover glass, diamati di bawah mikroskop. Pemeriksaan ektoparasit pada bagian insang dilakukan dengan cara memotong bagian insang menggunakan gunting kemudian diletakan pada cawan petri yang telah diberi aquades, kemudian lembaran insang diletakkan diobejck glass dilakukan pencacahan yang selanjutnya diamati di bawah mikroskop binokuler. Sedangkan untuk pemeriksaan ektoparasit pada bagian sirip dilakukan dengan memotong sirip menggunakan gunting, kemudian diletakkan pada object glass, untuk selanjutnya diamati dengan menggunakan mikroskop binokuler. Kemudian identifikasi dila-kukan
Pemeriksaan suhu dilakukan in situ dengan menggunakan termometer air raksa, pada beberapa titik pengamatan. Termometer dicelupkan secara langsung kedalam air waduk selama kurang lebih satu menit, kemudian dilakukan pencatatan suhu berdasarkan angka pengamatan pada termometer tersebut.

Pengamatan $\mathrm{pH}$ menggunakan kertas indikator dengan kisaran nilai $\mathrm{pH}$ dari 1 - 14. Tahapan pelaksanaan penguuran $\mathrm{pH}$ diawali dengan mencelupkan beberapa kertas indikator pada beberapa titik pengamatan, selanjutnya perubahan warna pada kertas indikator 
tersebut distandarkan dengan warna pada kotak indikator $\mathrm{pH}$.

Pengamatan nilai oksigen terlarut (DO) pada prinsipnya menggunakan metoda Winkler, walaupun pada pelaksanaannya dapat menggunakan test kit ataupun peralatan laboratorium (buret, erlenmeyer). Metode titrasi dengan cara Winkler secara umum banyak diunakan untuk memnentukan kadar oksigen terlarut. Prinsipnya dengan menggunakan titrasi lodometri. Sampel yang akan dianalisis, terlebih dahulu ditambahkan larutan $\mathrm{MnCl}_{2}$ dan $\mathrm{NaOH}$ atau $\mathrm{KI}$, sehingga akan terkjadi endapan $\mathrm{MnO}_{2}$. Dengan menambahkan $\mathrm{H}_{2} \mathrm{SO}_{4}$ atau $\mathrm{HCl}$ maka endapan yang terjadi akan larut kembali dan juga akan membebaskan molekul lodium $\left(\mathrm{I}_{2}\right)$ yang ekivalen dengan oksigen terlarut. Iodi-um yang dibebaskan ini selanjutnya akan dititrasi dengan larutan standar natrium tiosulfat $\left(\mathrm{Na}_{2} \mathrm{~S}_{2} \mathrm{O}_{3}\right)$ dan meng-gunakan larutan amilium.

Pengamatan nilai amoniak atau $\mathrm{NH}_{3}$ pada prinsipnya menggunaan metoda spektrofotometer. Metode spektrofotometer dilakukan berdasarkan absorban nilai tampakan oleh suatu larutan berwarna. Oleh karena itu metoda ini dikenal juga sebagai metoda kalorimeter. Kalorimeter dilakukan dengan membandingkan larutan standar dengan sampel yang dibuat padda kondisi yang sama dalam tabung Nessler. Jumlah cahaya yang diserap berbanding lurus dengan konsentrasi larutan.

\section{HASIL DAN PEMBAHASAN}

Hasil identifikasi identifikasi ektoparasit dari sampel yang berasal dari lima waduk lokasi penelitian, dapat dlihat pada Tabel 1.

Tabel 1. Hasil identifikasi ekoparasit sampel ikan mas dari Waduk Jatiluhur

\begin{tabular}{lllll}
\hline No. & \multicolumn{1}{c}{ Jenis parasit } & Prevalensi & Intensitas & Dominansi \\
\hline 1 & Trichodina sp. & 20 & 72,33 & 7,89 \\
2 & Ichthyophthirius multifilis & 6,67 & 9 & 0,33 \\
3 & Epistylis sp. & 13,33 & 48,50 & 3,52 \\
4 & Vorticella sp. & 6,67 & 4 & 0,15 \\
5 & Argulus sp. & 20 & 1,67 & 0,18 \\
6 & Gyrodactylus sp. & 6,67 & 2 & 0,07 \\
7 & Dactylogyrus sp. & 100 & 145,87 & 79,51 \\
8 & Cichlidogyrus sp. & 40 & 37,50 & 8,18 \\
9 & Diplozoon sp. & 13,33 & 1 & 0,07 \\
10 & Heterobothrium $\mathrm{sp}$. & 6,67 & 3 & 0,11 \\
\hline
\end{tabular}


Berdasarkan Tabel 1. sampai Tabel 5., dapat diketahui bahwa terdapat empat jenis ektoparasit yang ditemukan pada seluruh waduk yang menjadi lokasi penelitian. Ektoparasit tersebut adalah:

Trichodina sp., Diplozoon sp., Dactylogyrus sp., serta Cichlidogyrus sp, dengan nilai prevalensi tertinggi yaitu

Tabel 2. Hasil identifikasi ektoparasit sampel ikan mas dari Waduk Cirata

\begin{tabular}{ccccc}
\hline No. & Jenis parasit & Prevalensi & Intensitas & Dominansi \\
\hline 1 & Trichodina sp. & 26,67 & 1,75 & 0,19 \\
2 & Dactylogyrus sp. & 100 & 225,20 & 93,39 \\
3 & Cichlidogyrus sp. & 26,67 & 48,25 & 5,34 \\
4 & Diplozoon sp. & 33,33 & 1,60 & 0,22 \\
5 & Epistylis sp. & 6,67 & 10 & 0,28 \\
6 & Heterobothrium sp. & 20 & 7 & 0,58 \\
\hline
\end{tabular}

Tabel 3. Hasil identifikasi ektoparasit sampel ikan mas dari Waduk Saguling

\begin{tabular}{ccccc}
\hline No. & Jenis parasit & Prevalensi & Intensitas & Dominansi \\
\hline 1 & Trichodina sp. & 20 & 92 & 26,16 \\
2 & Argulus sp. & 13,33 & 6 & 1,14 \\
3 & Dactylogyrus sp. & 100 & 32 & 45,50 \\
4 & Cichlidogyrus sp. & 33,33 & 54,8 & 25,97 \\
5 & Diplozoon sp. & 13,33 & 1,5 & 0,28 \\
6 & Gyrodactylus sp. & 6,67 & 2 & 0,19 \\
7 & Heterobothrium sp. & 26,67 & 2 & 0,76 \\
\hline
\end{tabular}

Tabel 4. Hasil identifikasi ektoparasit sampel ikan mas dari Waduk Jatigede

\begin{tabular}{ccccc}
\hline No. & Jenis parasit & Prevalensi & Intensitas & Dominansi \\
\hline 1 & Trichodina sp. & 80 & 58,17 & 18,12 \\
2 & Argulus sp. & 13 & 1,50 & 0,08 \\
3 & Epistylis sp. & 60 & 227 & 53,04 \\
4 & Vorticella sp. & 27 & 31 & 3,22 \\
5 & Ichthyophthirius multifilis & 20 & 59 & 4,60 \\
6 & Diplozoon sp. & 13 & 1 & 0,05 \\
7 & Dactylogyrus sp. & 100 & 32,40 & 12,62 \\
8 & Cichlidogyrus sp. & 20 & 5,33 & 0,42 \\
9 & Gyrodactylus sp. & 53 & 37,88 & 7,87 \\
\hline
\end{tabular}


sebesar 100\% diperoleh Dactylogyrus sp. pada ikan sampel di seluruh lokasi. Nilai intensitas yang dicapai oleh ektoparasit Dactylogyrus sp. di waduk Cirata, Jatiuhur, Darma, Jatigede serta Saguling secara berurutan adalah 225,2; 145,87; 51,67; 32,4; 32. Dominansi ektoparasit ini tertinggi memiliki nilai 93,39 di waduk Darma; 79,52 di Jatiluhur; 45,5 di Saguling; 12,62 di Jati Gede serta 7,53 di waduk Darma (Gambar 1.). Sebaran Dactylogyrus di lima lokasi waduk penelitian, dihitung berdasarkan nilai Prevalensi (\%), Intensitas serta Dominansi (\%), dapat dilihat pada Gambar 1. Hasil dokumentasi ektoparasit Dactylogyrus sp. yang diperoleh dari hasil identifikasi sampel penelitian dapat dilihat pada Gambar 2.

Chaudhary (2017) menyatakan bahwa genus Dactylogyrus, merupakan salah satu parasit yang banyak ditemukan pada kelompok Cyprinus. Para-sit

Tabel 5. Hasil identifikasi ektoprasit sampel ikan mas dari Waduk Darma

\begin{tabular}{lllll}
\hline No. & \multicolumn{1}{c}{ Jenis parasit } & Prevalensi & Intensitas & Dominansi \\
\hline 1 & Trichodina sp. & 66,67 & 131,50 & 12,77 \\
2 & Argulus sp. & 26,67 & 1 & 0,04 \\
3 & Epistylis sp. & 66,67 & 715,40 & 69,49 \\
4 & Vorticella sp. & 26,67 & 61,25 & 2,38 \\
5 & Ichthyophthirius multifilis & 60 & 62 & 5,42 \\
6 & Diplozoon sp. & 20 & 2 & 0,06 \\
7 & Dactylogyrus sp. & 100 & 51,67 & 7,53 \\
8 & Cichlidogyrus sp. & 40 & 25,33 & 1,48 \\
9 & Gyrodactylus sp. & 66,67 & 8 & 0,78 \\
10 & Heterobothrium $\mathrm{sp}$. & 20 & 2 & 0,06 \\
\hline
\end{tabular}

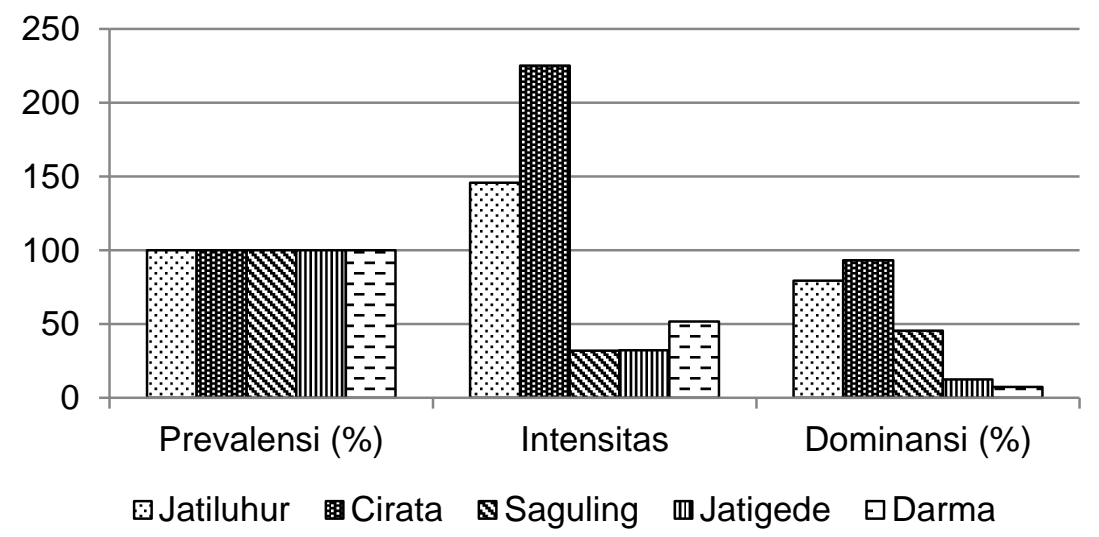

Gambar 1. Sebaran nilai ektoparasit Dactylogyrus sp. pada lokasi penelitian 

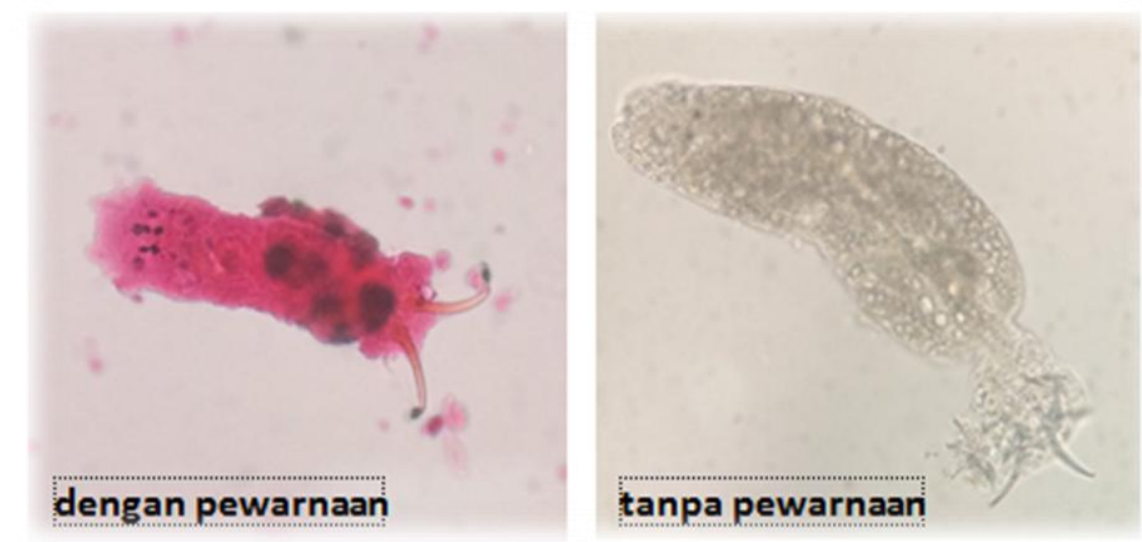

Gambar 2. Ektoparasit Dactylogyrus sp. pada sampel ikan

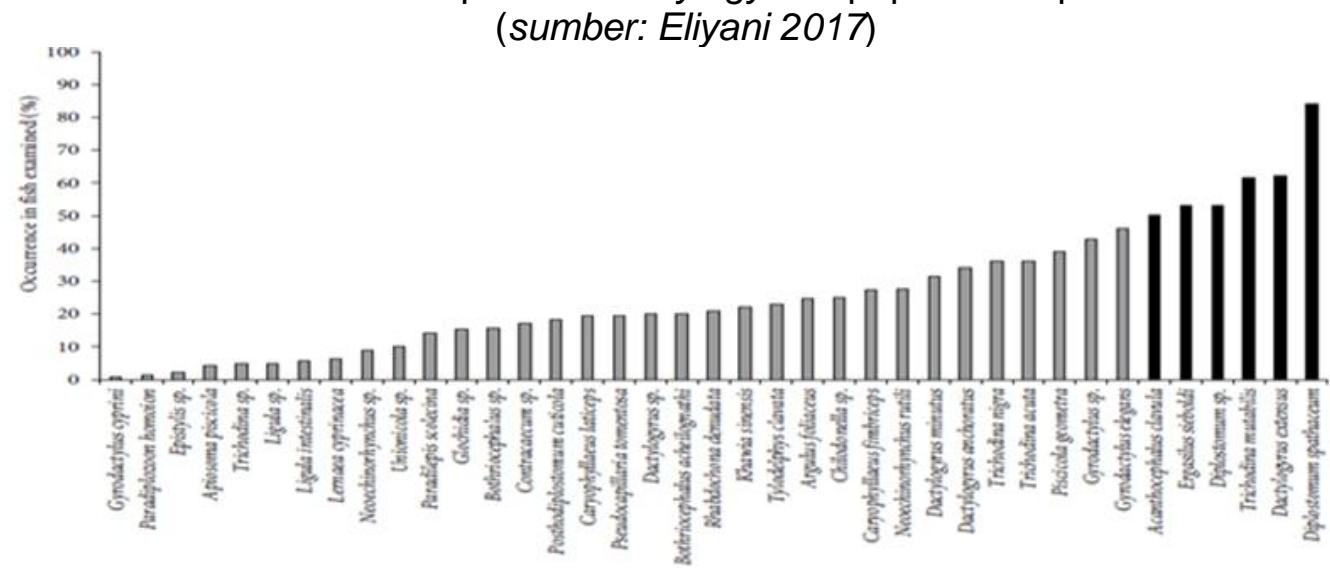

Gambar 3. Persentase keberadaan parasit pada ikan mas di Perairan Turki (sumber: Vallizi et al. 2015)

ini menginfeksi insang sehingga mengganggu proses respirasi, dan dalam jumlah yang besar akan menimbulkan mortalitas yang cukup signi-fikan. Villizzi et al. (2015) menyataan bahwa ektoparasit Dactylogyrus sp. me-rupakan salah satu parasit yang di-temukan menginfeksi ikan mas, apat dilihat pada Gambar 3. Dactylogyrus sp. umumnya menyerang insang ikan. Ozer \& Erdem (1999) dalam Juwahir et al. (2016) menemukan bahwa $92,5 \%$ D. Extensus umumnya ditemukan di insang baik pada ikan liar maupun ikan yang dibudidayakan, dan dari 70 hanya $6,7 \%$ species tersebut ditemukan menginfeksi kulit.

Bila Dactylogyrus ini menyerang insang dalam jumlah yang banyak dapat menyebabkan kematian karena pengeluaran lendir yang terlalu banyak dari insang, sehingga insang mengalami iritasi). Dactylogyrus sp., juga dapat menghisap darah dari pembuluh kapiler insang. Hal ini dapat melemahkan ikan sehingga dapat mengakibatkan kematian.Ektoparasit lainnya dari golongan monogenea yang ditemukan pada lima 


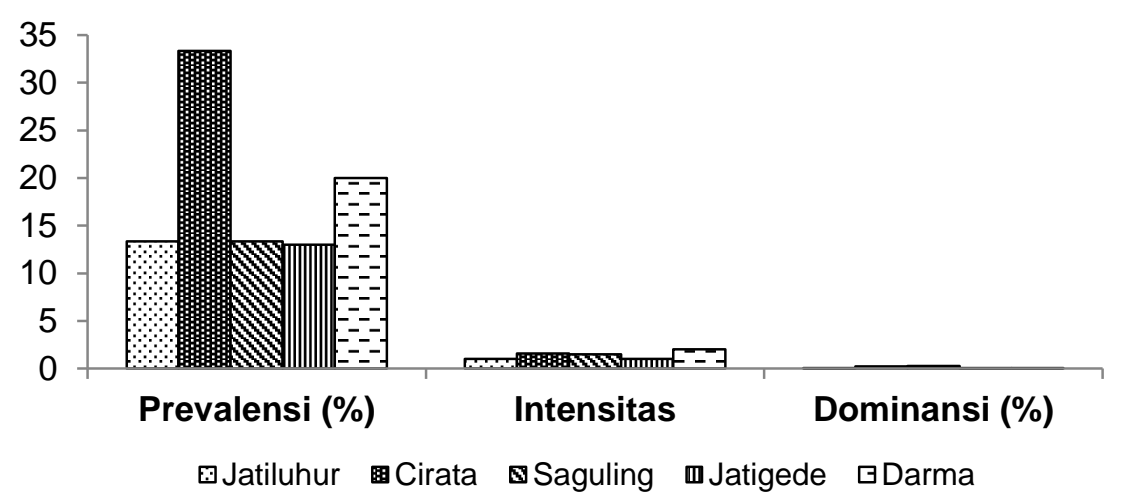

Gambar 4. Sebaran nilai ektoparasit Diplozoon sp. pada lima waduk lokasi penelitian

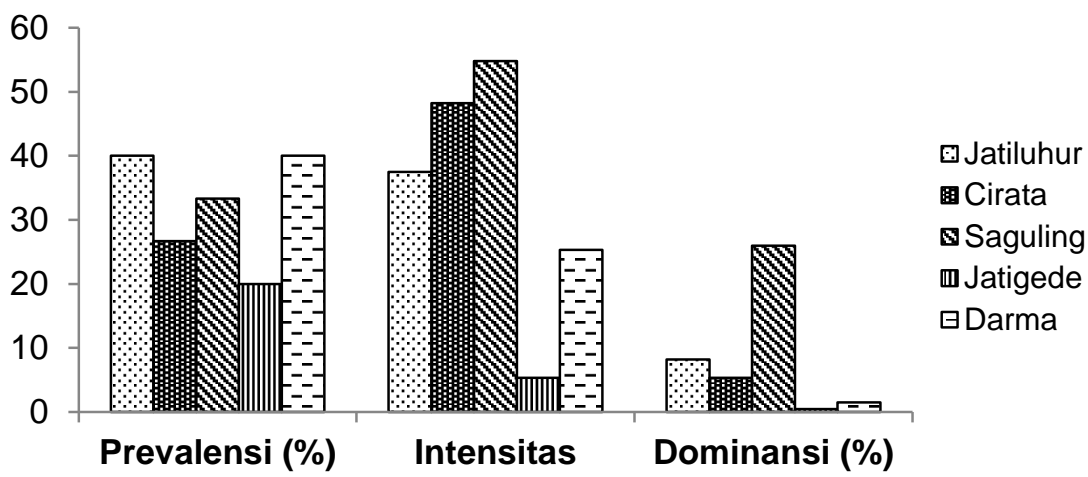

Gambar 5. Sebaran nilai ektoparasit Chiclidogyrus sp. pada lokasi penelitian

lokasi penelitian adalah Diplozoon sp. dan chicidogyrus sp. Sebaran kedua ektoprasit ini dapat dilihat pada Gambar 4. dan Gambar 5.

Berdasarkan Gambar diatas dapat diketahui bahwa parasit Diplozoon sp. memiliki nilai prevalensi tertinggi sebesar 33,33\% di waduk Cirata, disusul oleh sampel ikan yang berasal dari waduk Darma, Jatiluhur, Saguling, serta Jatigede, dengan nilai prevalensi maasing-asing sebesar 20\%; 13,33\%; 13,33\% dan 13\%. Prevalensi Chiclidogyrus sp. dengan nilai tertinggi diper-oleh dari sampel ikan yang berasal dari waduk
Jatiluhur dan Darma, kemudian waduk Saguling, Cirata serta Jatigede, dengan masing-masing memiliki nilai $40 \%$; $40 \%$; $33,33 \% ; 26,67 \%$ dan $20 \%$.

Adapun nilai intensitas Diplozoon sp. tertinggi dicapai oleh sampel ikan yang berasal dari waduk Darma kemudian Saguling, Cirata, Jatiluhur serta Jatigede dengan nilai sebesar 2; 1,6; 1,5; 1; dan 1. Untuk intensitas Cichlidogyrus sp. tertinggi dicapai oleh sampel ikan dari waduk Saguling, Cirata, Jatiluhur, Darma serta Jatigede dengan nilai sebesar 54,8; 48,25; 37,5; 25,33 serta 5,33. Tampilan parasit Chiclidogyrus sp dan Diplozoon 


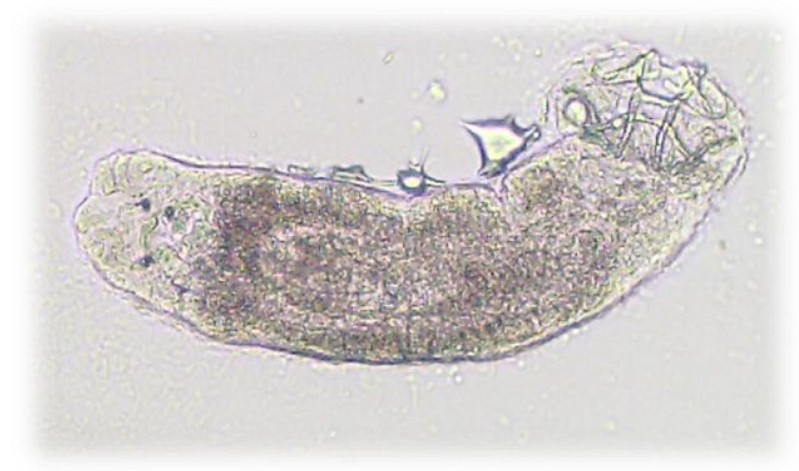

Gambar 6. Cichlidogyrus sp. perbesaran 100 (sumber: Eliyani 2017)

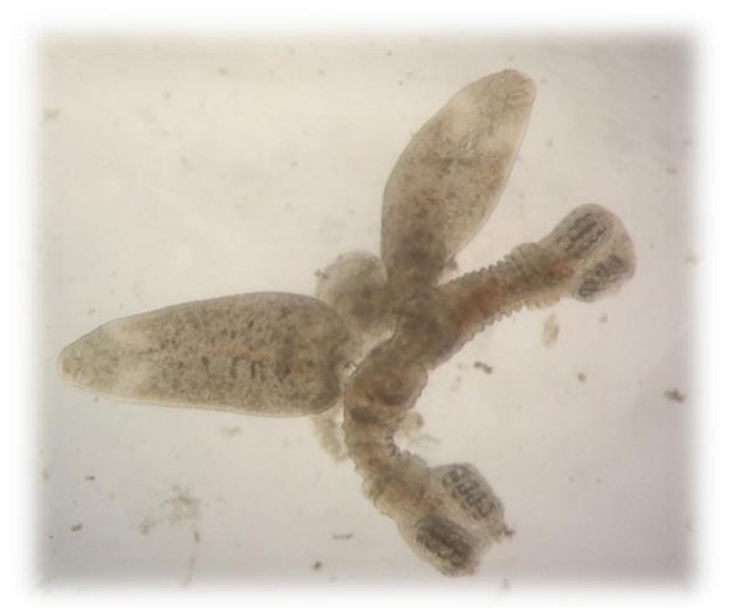

Gambar 7. Diplozoon sp. perbesaran 100 kali (sumber: Eliyani 2017)

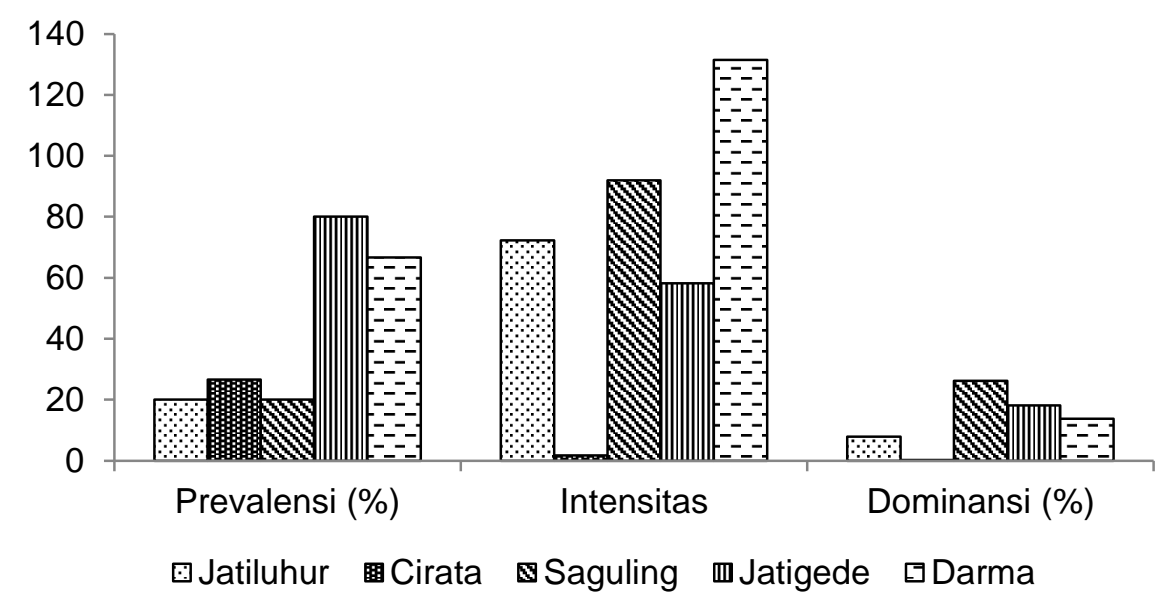

Gambar 8. Sebaran nilai ektoparasit Trichodina sp. pada lima waduk lokasi penelitian 


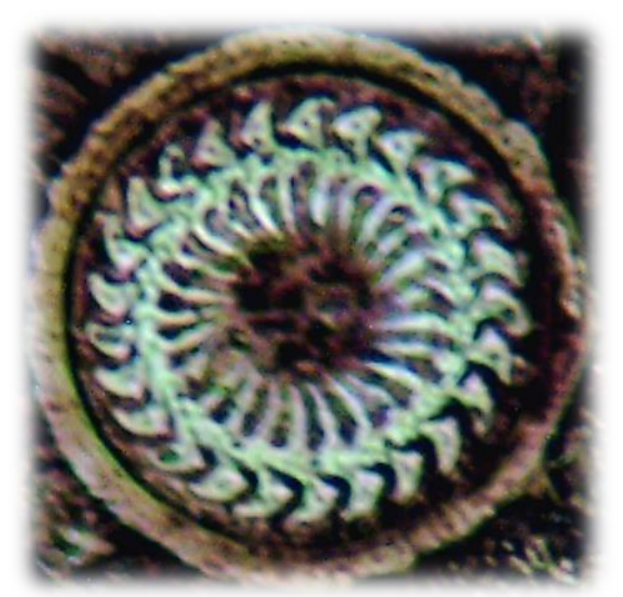

Gambar 9. Trichodina sp. perbesaran 400 kali (Eliyani et al. 2017)

pada Gambar 6. dan Gambar 7. chodiniasis tampak memiliki bintik putih Beberapa hasil penelitian menyatakan terutama di kepala dan punggung. bahwa banyak ektoparasit dari golongan Tampilan sebaran Trichodina sp. di monogenea yang berpin-dah ke inang baru melalui permukaan tubuh, kemudian membentuk koloni, dan hal ini sangat memungkinkan se-bagai jalan masuk untuk timbulnya in-feksi sekunder (Gonzalez et al. 2015, Trujillo-Gonz_alez 2014, Razo et al. 2016, Fey et al. 2015).

Parasit lainnya yang ditemukan di lima waduk lokasi penelitian adalah Trichodina sp. Ektoparasit ini menginfeksi bagian insang dan kulit ikan mas. Trichodina sp. dapat berpindah dari satu lokasi ke lokasi lain pada tubuh dengan jalan merangkak. Kulit yang terinfeksi mengalami peradangan, nekrosis dan berlendir. Menurut Usman (2007) da-lam Juwahir et al. (2016), Trichodina sp. menimbulkan penyakit gatal (trichodiniasis), terutama pada ikan yang sedang diberok. Ikan yang terserang trilokasi penelitian dapat disimak pada Gambar 8.

Berdasarkan Gambar 8, terlihat bahwa nilai prevalensi tertinggi dari ektoparasit Trichodina sp. dicapai dari sampel ikan waduk Jatigede, kemudian Darma, Cirata, Jatiluhur serta Saguling, dengan nilai masing-masing sebesar $80 \%$; $66,67 \%$; 26,67\%; 20\%, 20\%.

Adapun nilai tertingi intensitas diper-oleh sampel ikan Darma, selanjutnya Saguling, Jatiluhur, Jatigede serta Cirata, dengan nilai sebesar 131,5; 92; 72,33; 58,$17 ; 1,75$. Nilai dominansi Trichodina sp. tertinggi dicapai oleh sampel ikan Saguling, kemudian Jati-gede, Darma, Jatiluhur serta Cirata, dengan nilai sebesar 26,16; 18,12; 12,77; 7,89; 0,19. Kajian beberapa pa-kar menunjukkan menyatakan bahwa Trichodina sp. 
merupakan parasit dari golongan protozoa, sering ditemukan pada hampir seluruh siklus hidup ikan. Parasit ini tidak memiliki inang spesifik (lqbal \& Fauzia 2014, Alamdari et al. 2017)

Tingkat infeksi yang tinggi dipicu oleh banyaknya kandungan bahan organik di perairan. Trichodina sp. dapat ditemukan pada permukaan tubuh dan insang, yang dapat menjadi pintu masuk bagi patogen lainnya (infeksi sekunder). Tampilan Trichodina sp. yang ditemukan pada lokasi penelitian dapat dilihat pada Gambar 9.

\section{SIMPULAN}

Hasil identifikasi menunjukkan terdapat 10 jenis ektoparasit yang ditemukan, yaitu Trichodina sp., Ichthyophthirius multifilis, Epistylis sp., Vorti-cella sp., Argulus sp., Gyrodactylus sp., Dactylogyrus sp., Cichlidogyrus sp., Diplozoon sp., Heterobothrium sp. Dari 19 ektoparasit ini, terdapat 4 jenis ektoparasit yang ditemukan di semua lokasi penelitian yaitu: Trichodina sp., Diplozoon sp., Dactylogyrus sp., Cichlidogyrus sp.; dengan kisaran nilai prevalensi (\%) 10 - 100; nilai intensitas sebesar 1 - 225,2; dan rentang nilai dominansi \% sebesar 0,05-93,39.

\section{DAFTAR PUSTAKA}

Alamdari A, G Manshadi AR, Tarahomi M. 2017. External Parasitic Worms and Protozoans of the Fish Caught in Shapour River and Seyyed Hossein Spring in Ka-zerun, Iran. Journal of Alternative Veterinary Medicine, Kazerun Branch, Islamic Azad University, 1(1): 25-36

Chaudhary AC, HR Chiary, HS Singh. 2017. First molecular confir-mation of the Dactylogyrus anchoratus and D. vastator (Monogenea, Dactylogyridae) from Carassius auratusin western India. Bio Invasions Records, 6(1): 79-85

Eliyani Y, ODS Hasan, LS Syafei, Sujono. Identifikasi infeksi ektoparasit pada ikan mas (Cyprinus carpio) di jaring apung Waduk Cirata dan Waduk Ir. H. Juanda Jawa Barat. 2017. Prosiding Simposium Nasional Ikan dan Perikanan, Jilid I: 589-600. Penerbit: Masyarakat Iktiologi Indonesia

Eliyani Y. 2017. Identifikasi infeksi ektoparasit pada ikan mas (Cyprinus carpio L.) di jaring apung Waduk Darma, Kabupaten Kuningan, Provinsi Jawa Barat. Jurnal Penyuluhan Perikanan dan Kelaut-an, 2(2): 67-79

Fey A, D Ben'itez-Villa, GE de Le'on, G P'erez-Ponce, RG Miguel. Population dynamics of Cichlidogyrus spp. and Scutogyrus sp. (Monogenea) infecting farmed tilapia in Veracruz, M'exico, $A q$ - 
uaculture, (2015), doi: 10.1016/ j.aquaculture.2015.03.004

Gonzalez AT, CC Constantinoiu, R Rowe, KS Hutson. 2015. Tracking transparent monogenean parasites on fish from infection to maturity. International Journal for Parasitology: Parasites and Wildlife, 4: 316-322

Gonzalez MP, Muñoz JLP, ValerioV, LV Chacoff. 2016. Short Communication: Effects of the ectoparasite Caligus rogercresseyi on Salmosalar blood parameters under farm conditions. Aquaculture, (457): 29-34

Harsono E. 2016. Model eutrofikasi 2dimensi berlapis untuk optimalisasi lokasi zona budidaya ikan karamba jaring apung (KJA) di Waduk Jatiluhur (two-dimensi-onal layered eutrophication model to optimize the aquaculture float-ing net (KJA) zones location in Jatiluhur Reservoir). Jurnal Bio-logi Indonesia, 12(1): 277-289

Hashimoto GSO, Neto FM, Ruiz,ML, Acchile M,Chagas EC, Chaves FCM, Martins ML. 2016. Es-sential oils of Lippia sidoides and Mentha piperita against monoge-nean parasites and their influence on the hematology of Nile tilapia. Aquaculture, (450): 182-186.
Hermawaty Al. 2015. Permasalahan kelembagaan pemanfaatan waduk darma untuk kegiatan budidaya keramba jaring apung di Kabupaten Kuningan Jawa Barat. Jurnal Wilayah dan Lingkungan, 3(2): 95104.

lqbal Z, F Haroon. 2014. Parasitic Infections of Some Freshwater Ornamental Fishes Imported in $\mathrm{Pa}$ kistan. Pakistan Journal of Zoology., 46(3): 651-656

Juwahir A, Z Raihani Ya'la, Rusaini. 2016. Prevalensi dan intensitas ektoparasit pada ikan mas (Cyprinus carpio L.) di Kabupaten Sigi. Jurnal Agrisains, 17(2): 68-75

Marlan, SK Agustina. 2014. Analisis prevalensi parasit yang menginfeksi benih ikan nila (Oreochromis niloticus) pada sentra pembenihan di wilayah Kabu-paten Banggai. Jurnal Balik Di-wa, 5(2): Juli-Desember

Novia F. 2016. Potensi beban pencemaran nitrogen dari inlet sungai ke waduk Cirata, Jawa Barat. Seminar Nasional Sains dan Tek-nologi Lingkungan II, e-ISSN 2541-3880

Ogawa K, S Shirakashi, H Ishitani. 2014. Insemination of the mono-genean Neobenedenia girellae (Capsalidae, Benedeniinae). Para- 
sitology International Journal, 63: 473-478

Razo-Mendivil U, Garc'ı-V'asquez A, Rubio-Godoy M. 2016. Spot the difference: two cryptic species of Gyrodactylus von Nordmann, 1832 (Platyhelminthes: Mono-genea) infecting Astyanax aeneus (Actinopterygii, Characidae) in Mexico. Parasitology Internati-onal (2016), doi: 10.1016/j.parint. 2016.05.009

Rolin C, Graham J, McCarthy U, Mar-tin SAM, Matejusova I. 2016. Interactions between Paramoeba perurans, the causative agent of amoebic gill disease, and the bluemussel, Mytilusedulis. Aquaculture, (456): 1-8

Skov J, Mehrdana F, Marana MH, Bahlool QZM, Jaafar RM, Sindberg D, Jensen HM, Kania P, Buchmann K. 2014. Parasite in-fections of rainbow trout (Oncorhynchusmykiss) from Danish mariculture. Aquaculture, (434): 486-492

Trujillo-Gonz_alez A, Constantinoiu CC, Johnson LK, Hutson KS. 2014. Histopathology associated with haptor attachment of the ectoparasitic monogenean Neobenedenia sp. (Capsalidae) to Asian sea bass, Lates calcarifer (Bloch). Jounal of Fish Diseas
Vilizzi L, AS Tarkan, FG Ekmekçi. 2015. Parasites of the common carp Cyprinus carpio L., 1758 (Teleostei: Cyprinidae) fromwater bodies of Turkey: updated checklist and review for the 1964-2014 period. Turkey Journal of Zoology,(39): 545-554 